Primljeno: 26.9.2018.

Prihvaćeno: 9.7.2019.

DOI: https://doi.org/10.36506/av.62.5

\author{
Ivan Brigović \\ Hrvatski memorijalno-dokumentacijski centar Domovinskog rata \\ Zagreb, Hrvatska \\ ivan.brigovic@centardomovinskograta.hr \\ Josipa Caričić \\ Hrvatski državni arhiv \\ Zagreb, Hrvatska \\ jcaricic@arhiv.hr
}

\title{
PRIKUPLJANJE, OBRADA I KORIŠTENJE ARHIVSKOGA GRADIVA 9. (KNINSKOG) KORPUSA JUGOSLAVENSKE NARODNE ARMIJE U HRVATSKOM MEMORIJALNO-DOKUMENTACIJSKOM CENTRU DOMOVINSKOG RATA U ZAGREBU
}

\author{
UDK: 355.48(497.5)“1991/1995“(093.2) \\ 355.311.4(497.1)“1991/1992“ \\ 930.253:355(497.521.2)(093) \\ Pregledni rad
}

U Hrvatskom memorijalno-dokumentacijskom centru Domovinskog rata $u$ Zagrebu cuva se arhivski fond 9. korpus Jugoslavenske narodne armije, obima pedeset $i$ osam kutija (5,8 dužnih metara) gradiva nastaloga od 1972. do 1992. godine. Fond izvorno nije cinio jednu organsku cjelinu, nego je nastao izdvajanjem gradiva korpusa iz više dokumentacijskih cjelina tijekom višegodišnjega razdoblja. Uslijed toga, fond je arhivistički obradivan u tri faze te je završen u lipnju 2018. godine. Izradeno je obavijesno pomagalo (sumarni inventar). Gradivo je javno i dostupno svim korisnicima koji Hrvatskomu memorijalno-dokumentacijskomu centru Domovinskoga rata podnesu zahtjev za uvid u sadržaj i pretraživanje fonda. Gradivo je autentično, dobro očuvano i vjerodostojno. Navedeni fond ima veliku informacijsku vrijednost te je iznimno važan povijesni izvor za proučavanje Domovinskog rata na 
Brigović I., Caričić J. Prikupljanje, obrada i korištenje arhivskoga gradiva 9. (kninskog) korpusa Jugoslavenske narodne armije u Hrvatskom memorijalno-dokumentacijskom centru Domovinskog rata u Zagrebu Arh. vjesn. 62 (2019), str. 107-126

području sjeverne Dalmacije i južne Like od 1991. do 1992., za proučavanje izbijanja rata u Bosni i Hercegovini u proljeće 1992., kao i za razumijevanje uloge Jugoslavenske narodne armije u raspletu jugoslavenske krize.

Ključne riječi: arbivsko gradivo; arhivski fondovi i zbirke; arbivistička obrada; dostupnost gradiva; informacijska vrijednost; specijalizirani arhiv; Domovinski rat; 9. korpus Jugoslavenske narodne armije; kninski korpus Jugoslavenske narodne armije

\section{Uvod}

Temeljne su zadaće svakoga arhiva, pa tako i Hrvatskoga memorijalnodokumentacijskoga centra Domovinskog rata (HMDCDR), čuvanje, obrađivanje i omogućavanje korištenja arhivskoga gradiva koje je u njima pohranjeno, sukladno odredbama Zakona o arhivskom gradivu i arhivima. ${ }^{1} \mathrm{U}$ HMDCDR-u u Zagrebu, specijaliziranom arhivu osnovanom radi prikupljanja, sredivanja, čuvanja i zaštite arhivskoga gradiva (službenih dokumenata, plakata, tiskovina, fotografija, videozapisa i memoarskoga gradiva - intervjua sa sudionicima pojedinih događaja te zapovjednicima i pripadnicima ratnih postrojbi) vezanoga za Domovinski rat, između ostaloga gradiva Jugoslavenske narodne armije (JNA), čuva se fond 9. korpus JNA. Riječ je o važnom i informacijski vrijednom gradivu za Republiku Hrvatsku koje je važan povijesni izvor za proučavanje najnovije hrvatske povijesti. U radu autori prikazuju kako je navedeno gradivo dospjelo kao depozit u HMDCDR te kako je tekao dugi proces njegova oblikovanja i arhivističke obrade. Pritom se željela naglasiti složenost arhivističkoga posla i brojne poteškoće $s$ kojima su se stručni djelatnici susreli prilikom sređivanja fonda, jer gradivo izvorno nije činilo jednu organsku cjelinu. Opisana je također informacijska vrijednost i uvjeti dostupnosti sačuvanoga gradiva s ciljem informiranja znanstvene, ali i šire javnosti, te poticanja daljnjega korištenja u znanstvene i druge svrhe.

\section{Oblikovanje fonda 9. korpus JNA i njegova arhivistička obrada}

Većinu arhivskoga gradiva 9. korpusa JNA, koje je pohranjeno u HMDCDR-u, zaplijenili su pripadnici Hrvatske vojske (HV) i Ministarstva unutarnjih poslova (MUP) Republike Hrvatske nakon oslobodilačke vojnoredarstvene operacije (VRO) Oluja. Gradivo je bilo dio obimne dokumentacije vojnih i civilnih institucija Republike Srpske Krajine (RSK), JNA, Vojske Jugoslavije (VJ) i Republike Srpske (RS), koja je pronađena na oslobođenom terito-

1 Zakon o arhivskom gradivu i arhivima, NN 61/2018. 
Brigović I., Caričić J. Prikupljanje, obrada i korištenje arhivskoga gradiva 9. (kninskog) korpusa Jugoslavenske narodne armije u Hrvatskom memorijalno-dokumentacijskom centru Domovinskog rata u Zagrebu Arh. vjesn. 62 (2019), str. 107-126

riju Republike Hrvatske u kolovozu 1995. godine. Veći dio navedenoga arhivskoga gradiva, zajedno $s$ gradivom zaplijenjenim nakon VRO Bljesak, preuzela je Protuobavještajna agencija (POA) MUP-a, a manji je dio preuzela Vojna sigurnosno-obavještajna agencija (VSOA) Ministarstva obrane Republike Hrvatske $(\mathrm{MORH})$. Temeljem ugovora, POA i VSOA predale su navedeno arhivsko gradivo u četiri navrata od ožujka do rujna 2004. na stručnu obradu i čuvanje Hrvatskomu državnomu arhivu (HDA) u Zagrebu, gdje je ono dobilo skupni naziv Izvorna civilna, vojna i policijska dokumentacija tzv. Republike Srpske Krajine. Prema dobivenim popisima od POA-e i VSOA-e, u preuzetoj dokumentaciji postojala je dokumentacijska cjelina opsega 4,9 dužnih metara (49 kutija/ registratora), koja je pretežno sadržavala gradivo 9. korpusa JNA. Gradivo je bilo u nesređenom stanju. Po preuzimanju nije spojeno u jednu cjelinu, nego je ostalo nesređeno, u stanju u kakvom je zaprimljeno. ${ }^{2}$

Po preuzimanju cjelokupnoga gradiva u HDA izrađen je plan sređivanja. Prvotno je planirana izrada shema ustroja vojnih jedinica, među kojima i 9. korpusa JNA, prema kojima bi se postupno sređivalo gradivo pojedinih stvaratelja. $\mathrm{Na}$ temelju popisa preuzetih zajedno s gradivom, u siječnju 2005. izrađen je Sumarni pregled sadržaja arhivskoga gradiva Republike Srpske Krajine 1991.-1995. koje se nalazi u $H D A{ }^{3}$ Fizičko sređivanje gradiva 9. korpusa JNA u HDA nije započelo, jer je ono, temeljem Ugovora o pohrani, 14. prosinca 2005. predano u depozit HMDCDR-u, u kojem se od tada čuva. Dokumentacija mu je predana na stručnu obradu i sigurnosnu pohranu, pri čemu se HMDCDR obvezao da će ju čuvati u skladu s načelima arhivističke struke i odredbama Zakona o arhivskom gradivu i arhivima. ${ }^{4}$

Preuzeto gradivo, među kojim i gradivo 9. korpusa JNA, u HMDCDR-u je dobilo naziv Paradržavne i paravojne postrojbe na okupiranom području Republike Hrvatske. U skladu sa svojim temeljnim zadaćama, HMDCDR je nastavio $s$ kontinuiranim prikupljanjem i drugih cjelina arhivskoga gradiva u vezi s Domo-

\footnotetext{
2 Hrvatski memorijalno-dokumentacijski centar Domovinskog rata, Pismohrana (dalje: HMDCDR, Pismohrana), Kl: 612-06/05-08/36, ur. broj: 565-10-05-1, Zagreb, 14. 12. 2005., Ugovor o pohrani, Prilog br. 1, Popis zaplijenjene neprijateljske dokumentacije i druge građe, Zagreb, 8. 7. 2004., Prilog br. 2, Popis zaplijenjene neprijateljske dokumentacije i druge građe, Zagreb, 8. 7. 2004., Prilog br. 1, Popis zaplijenjene dokumentacije tzv. RSK koju MORH predaje u HDA, rujan 2004., Prilog, Izvorna civilna, vojna i policijska dokumentacija tzv. RSK (popis gradiva), Prilog, Hrvatski državni arhiv, Odsjek za arhivsko gradivo vojne provenijencije, Milan Pojić, Zagreb, 11. 1. 2005., Prijedlog plana sređivanja arhivskog gradiva Republike Srpske Krajine 1991.-1995. koje se nalazi u Hrvatskom državnom arhivu.

3 HMDCDR, Pismohrana, Kl: 612-06/05-08/36, ur. broj: 565-10-05-1, Zagreb, 14. 12. 2005., Ugovor o pohrani, Prilog, Hrvatski državni arhiv, Odsjek za arhivsko gradivo vojne provenijencije, Milan Pojić, Zagreb, 11. 1. 2005., Prijedlog plana sređivanja arhivskog gradiva Republike Srpske Krajine 1991.-1995. koje se nalazi u Hrvatskom državnom arhivu.

4 HMDCDR, Pismohrana, Kl: 612-06/05-08/36, ur. broj: 565-10-05-1, Zagreb, 14. 12. 2005., Ugovor o pohrani.
} 
vinskim ratom, koje su sadržavale i gradivo 9. korpusa JNA. Tako je u srpnju 2008. od MORH-a preuzeto gradivo JNA i RSK, zaplijenjeno tijekom vojnoredarstvenih operacija Gusar i Oluja. Između ostaloga, preuzet je 41 registrator arhivskoga gradiva, među kojim je bila znatna količina gradiva 9. korpusa JNA - uglavnom Komande korpusa i 180. motorizirane brigade. Gradivo je čuvano u vojarni u Zemuniku Donjem. ${ }^{5}$

U listopadu 2008. godine iz Središnjega vojnog arhiva (SVA) MORH-a preuzeto je, bez popisa i u rinfuznom stanju, 40 dužnih metara gradiva JNA te vojnih jedinica i civilnih ustanova RSK, nastaloga na okupiranom području Like tijekom Domovinskoga rata. Među njime bila je veća količina gradiva 9. korpusa JNA, prvenstveno 1 . motorizirane brigade. ${ }^{6}$

U studenom 2010. godine VSOA je predala HMDCDR-u trideset registratora gradiva RSK, JNA, VJ i iz razdoblja Socijalističke Republike Hrvatske (SRH). Među navedenim gradivom, za koje je VSOA izradila analitički inventar, bilo je dokumentacije 9. korpusa JNA, uglavnom disciplinskih mjera i kaznenih prijava Komande korpusa i komandi 9. bataljona vojne policije, 180. i 221. motorizirane brigade. ${ }^{7}$ Manju količinu gradiva 9. korpusa JNA sadržavalo je i 28 registratora dokumenata o Domovinskom ratu, preuzetih u veljači 2011. od Državnoga arhiva u Zadru. ${ }^{8}$ Znatnu količinu gradiva 9. korpusa JNA sadržavale su i analitički popisane dokumentacijske cjeline gradiva JNA, Teritorijalne obrane (TO) SRH, TO RSK i Srpske vojske Krajine (SVK), preuzete od VSOA-e u tri navrata tijekom 2011. i 2012. godine. Riječ je o dokumentaciji Komande 9. korpusa JNA i jedinica iz njegova sastava - Komande 221. motorizirane brigade, 180. motorizirane brigade, 1 . motorizirane brigade, 9. mješovitoga artiljerijskog puka i 11. proleterske motorizirane brigade/11. motorizirane brigade. ${ }^{9}$

5 HMDCDR, Pismohrana, Kl: 612-06/08-16/01, ur. broj: 5-08-04, Zagreb, 7. 7. 2008., Službena zabilješka.

6 HMDCDR, Pismohrana, Kl: 612-06/09-16/04, ur. broj: 568-02-09-01, Zagreb, 22. 7. 2009., Službena bilješka.

7 HMDCDR, Pismohrana, Kl: 612-06/10-16/05, ur. broj: 568-06-10-01, Zagreb, 15. 11. 2010., Zapisnik o primopredaji arhivskoga gradiva civilnih i vojnih ustanova na okupiranom području RH 1991.-1995.

8 HMDCDR, Pismohrana, Kl: 612-06/11-16/02, ur. broj: 568-01-11-02, Zagreb, 25. 02. 2011., Zapisnik o primopredaji arhivskoga gradiva civilnih i vojnih ustanova na okupiranom području RH 1991-1995. između Državnog arhiva u Zadru i Hrvatskog memorijalno-dokumentacijskog centra Domovinskog rata iz Zagreba.

9 HMDCDR, Pismohrana, Kl: 612-06/11-16/01, ur. broj: 568-06-11-02, Zagreb, 7. 4. 2011., Zapisnik o primopredaji arhivskoga gradiva između Vojno sigurnosne obavještajne agencije i Hrvatskog memorijalno-dokumentacijskog centra Domovinskog rata, Kl: 612-06/11-16/01, ur. broj: 568-06-1103, Zagreb, 5. 12. 2011., Zapisnik o primopredaji arhivskoga gradiva između Vojno sigurnosne obavještajne agencije i Hrvatskoga memorijalno-dokumentacijskog centra Domovinskog rata, Kl: 612-06/1202/18, ur. broj: 568-01-12-01, Zagreb, 3. 5. 2012., Zapisnik o primopredaji arhivskoga gradiva između Vojno sigurnosne obavještajne agencije i Hrvatskog memorijalno-dokumentacijskog centra Domovinskog rata. 
Brigović I., Caričić J. Prikupljanje, obrada i korištenje arhivskoga gradiva 9. (kninskog) korpusa Jugoslavenske narodne armije u Hrvatskom memorijalno-dokumentacijskom centru Domovinskog rata u Zagrebu Arh. vjesn. 62 (2019), str. 107-126

Znatnu količinu dokumentacije 9. korpusa JNA sadržavala su i 23 fascikla, odnosno 21 registrator nesređenoga gradiva hrvatske i srpske provenijencije iz razdoblja Domovinskoga rata, preuzetog u prosincu 2013. od Jadranka Kaleba iz Zadra. ${ }^{10}$

U ožujku 2018. Pavle Vranjican predao je HMDCDR-u gradivo JNA i SVK, nastalo između 1985. i 1992. godine. Između ostaloga, predao je pet arhivskih kutija gradiva, među kojim je većinu sačinjavala dokumentacija 9. bataljona vojne policije. ${ }^{11}$

Policijska uprava ličko-senjska predala je HMDCDR-u dva registratora gradiva nastaloga na okupiranom području Like tijekom Domovinskoga rata. Među njime bilo je i nešto gradiva - dokumenata (originala i kopija) i rokovnika -9. korpusa JNA, prvenstveno 1 . motorizirane brigade. ${ }^{12}$

Uvidom u popise preuzete od HDA zajedno s gradivom, uočeno je da fond 9. korpus JNA, kao i svi drugi fondovi u preuzetom gradivu, ne čini organsku cjelinu i da treba pregledati $49 \mathrm{kutija} /$ registratora koji su pretežno sadržavali gradivo korpusa, kako bi ga se objedinilo. Uz to, trebalo je pregledati i 219 kutija/ registratora u kojima se, prema spomenutim popisima, nalazilo arhivsko gradivo opisano kao Jedinice JNA i VJ na području Republike Hrvatske i Ostala nerazvrstana dokumentacija, jer je i u njima moglo biti gradiva korpusa. Pritom je uočeno da se velik broj dokumenata 9. korpusa JNA nalazi u cjelini korištenoj za izradu Memorijala za tužbu protiv Jugoslavije zbog kršenja odredbi Konvencije o genocidu, iz koje nisu smjeli biti izdvojeni prije okončanja postupka pred Međunarodnim sudom pravde u Haagu. To je onemogućavalo cjelovito sređivanje fonda 9. korpus JNA. Zbog takve situacije, odlučeno je da će se, prilikom pregledavanja i sređivanja gradiva ostalih fondova, izdvojiti sva dokumentacija 9. korpusa JNA na koju se naiđe, objediniti na jedno mjesto i djelomično razvrstati po stvarateljima. Pritom je trebalo identificirati organizacijski ustroj 9. korpusa JNA, koji je u drugoj polovici 1991. i prvoj polovici 1992. doživio značajne strukturne promjene, kako bi se znalo koje sve gradivo čini sastavni dio fonda. Uvidom u samo gradivo te relevantne znanstvene radove i druge dokumente koji su sadržavali korisne informacije o fondu, identificiran je organizacijski ustroj i utvrđene su hijerarhijske veze u 9. korpusu JNA. ${ }^{13}$ Vodeći se time da je 9. korpus JNA vojna jedinica, hijerarhijski ustrojena, definirana je sljedeća struktura fonda:

10 HMDCDR, Pismohrana, Kl: 612-06/13-02/14, ur. broj: 568-02/1-13-01, Zagreb, 23. 12. 2013., Zapisnik o primopredaji arhivskoga gradiva. Arhivsko gradivo srpske provenijencije predano je na trajnu pohranu, a gradivo hrvatske provenijencije predano je na sređivanje i digitalizaciju, nakon čega je vraćeno Jadranku Kalebu.

11 HMDCDR, Pismohrana, Kl: 612-06/18-03/04, ur. broj: 568-01-18-03, Zagreb, 16. 3. 2018., Kupoprodajni ugovor.

12 Autori nisu uspjeli utvrditi datum kada je HMDCDR dobio navedeno gradivo.

13 U identifikaciji organizacijskoga ustroja korpusa autorima su najviše pomogle sljedeće monografije: Davor Marijan, Slom Titove armije: JNA i raspad Jugoslavije 1987.-1992. (Zagreb: Golden marketing, 


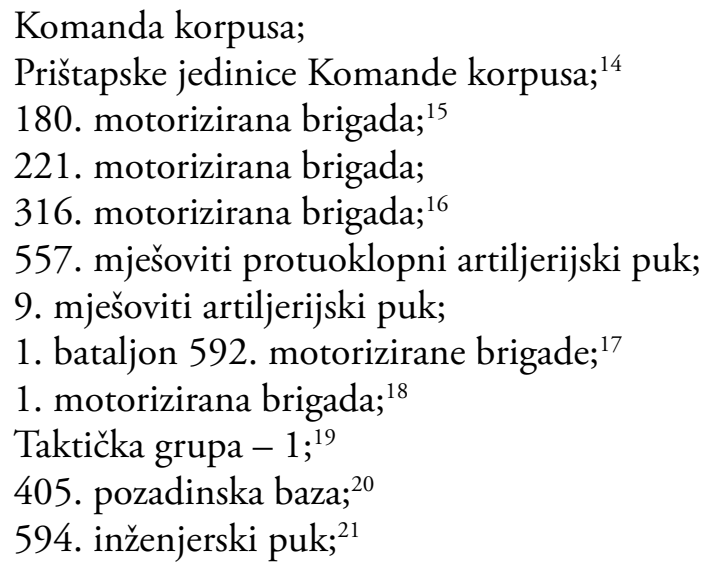

2008); Ante Nazor i Ivan Brigović, Zapovjedni vrh JNA: siječanj 1990. - svibanj 1992. (Zagreb: Hrvatski memorijalno-dokumentacijski centar Domovinskog rata, 2010); Davor Marijan, Domovinski rat (Zagreb: Despot infinitus, 2016).

14 Krajem kolovoza ili početkom rujna 1991. na područje sjeverne Dalmacije, kao ojačanje korpusu, došao je oklopni bataljon 10. motorizirane brigade iz Mostara, koji je u sastavu korpusa djelovao kao 9. oklopni bataljon. Marijan, Slom Titove armije, str. 306; Nazor i Brigović, Zapovjedni vrh JNA, str. 199.

15 Krajem kolovoza ili početkom rujna 1991. na područje sjeverne Dalmacije, kao ojačanje korpusu, došao je bataljon 4. proleterske motorizirane brigade iz Pirota, koji je ušao u sastav 180. motorizirane brigade kao njezin 1. bataljon. Marijan, Slom Titove armije, str. 306; Nazor i Brigović, Zapovjedni vrh JNA, str. 199.

16 Jedinica je ugašena u ljeto 1991. godine. Nazor i Brigović, Zapovjedni vrh JNA, str. 199.

17 Jedinica je došla s područja Kumanova na područje sjeverne Dalmacije kao ojačanje korpusu i ušla je u njegov sastav krajem kolovoza ili početkom rujna 1991. godine. Marijan, Slom Titove armije, str. 306; Nazor i Brigović, Zapovjedni vrh JNA, str. 199.

18 Komanda 9. korpusa ustrojila je jedinicu 19. rujna 1991. kao 1. partizansku brigadu TO-a, koja je $\mathrm{u}$ drugoj polovici prosinca iste godine preustrojena u 1. motoriziranu brigadu JNA. U izvorima brigada se od 24. rujna do 17. listopada spominje kao 1. partizanska brigada, a od 17. listopada do 18. prosinca 1991. kao 1. brigada TO SAO Krajine. U razdoblju od 7. prosinca 1991. do 3. lipnja 1992. brigada se u izvorima spominje kao 1. brigada TO Sveti Rok, 1. motorizirana brigada (SAO Krajine) i 1. motorizirana brigada TO SAO Krajine. Opremljena je oružjem i vojnom opremom 316. motorizirane brigade, koje je JNA izvukla iz Sinja. Marijan, Slom Titove armije, str. 306 i 310; Marijan, Domovinski rat, str. 149, Nazor i Brigović, Zapovjedni vrh JNA, str. 199.

19 Jedinica je osnovana odlukom komandanta korpusa krajem listopada 1991. godine. Osim jedinica iz sastava 180. i 221. motorizirane brigade, u njezinu su se sastavu trebala nalaziti i dva bataljona pobunjenih Srba s područja SAO Krajine. Ivan Brigović, "Odlazak Jugoslavenske narodne armije s područja Zadra, Šibenika i Splita krajem 1991. i početkom 1992. godine,” Casopis za suvremenu povijest 43, br. 2 (2011): str. 441.

20 Jedinica je ušla u sastav korpusa u posljednjem tromjesečju 1991., a prethodno je bila izravno podređena Komandi Vojnopomorske oblasti. Nazor i Brigović, Zapovjedni vrh JNA, str. 199.

21 Jedinica je ušla u sastav korpusa u posljednjem tromjesečju 1991., a prethodno je bila izravno podređena Komandi Vojnopomorske oblasti. Nazor i Brigović, Zapovjedni vrh JNA, str. 199. 

Arh. vjesn. 62 (2019), str. 107-126

\section{1. laki artiljerijski raketni puk $\mathrm{PVO}{ }^{22}$}

11. proleterska motorizirana brigada/11. motorizirana brigada $;^{23}$ Operativna grupa $-11 .^{24}$

Nakon što je rekonstruiran organizacijski ustroj 9. korpusa JNA, iz drugih fondova izdvojeno je petnaest kutija dokumentacije korpusa, koja je djelomično razvrstana na serije sukladno njegovu ustroju. Time je završila "prva faza" sređivanja fonda.

"Druga faza" sređivanja započela je 2014. nakon što je završen postupak pred Međunarodnim sudom pravde u Haagu. Iz "zaštićene" cjeline gradiva korištene u tom postupku izdvojena je sva dokumentacija 9. korpusa JNA te je pridružena već prikupljenomu gradivu fonda. Tomu je pridružena i sva dokumentacija 9. korpusa JNA, koja je identificirana i izdvojena iz gradiva koje je u listopadu 2008. preuzeto od SVA MORH-a i u veljači 2011. od Državnoga arhiva u Zadru. Sve to objedinjeno je u jednu cjelinu te je započela arhivistička obrada i podjela na serije u skladu s organizacijskim ustrojem korpusa. Gradivo je sređeno prema načelu prvobitnoga reda, odnosno sustavu odlaganja kod stvaratelja. Spisi su izvorno razvrstavani na spise $s$ oznakom državna tajna, strogo povjerljivo, povjerljivo, interno i upravni postupak te opće spise. Posebno su bili izdvojeni i sređeni personalna dokumentacija, blagajnička izvješća, putni radni listovi, materijalne liste, ugovori, potvrde, reversi, platne liste i dnevnici rada. Takav sustav razdiobe konzistentno je proveden u svim serijama kako bi se postigla što bolja preglednost cjelokupne strukture fonda. Prilikom arhivističke obrade izlučeno je vrlo malo gradiva, samo prazni listovi, multiplikanti i neispunjeni obrasci. $\mathrm{Na}$ taj način izdvojeno je trideset kutija (tri dužna metra) gradiva fonda 9. korpus JNA, koji je evidentiran pod signaturu HR-HMDCDR-7. Kako je opisano, gradivo je razvrstano po načelu prvobitnoga reda u petnaest serija s pripadajućim podserijama. U travnju 2015. izrađen je sumarni inventar. ${ }^{25}$

\footnotetext{
22 Jedinica je prethodno bila podređena Komandi Vojnopomorske oblasti i bila je smještena u Šepurinama kod Zadra. Cjelokupna jedinica evakuirana je iz Šepurina između 11. i 26. listopada 1991., tijekom odlaska jedinica JNA i JRM s područja Zadra. Po izvlačenju jedinica je ušla u sastav 9. korpusa JNA. Brigović, "Odlazak jedinica JNA," str. 429 i 433.

23 Jedinica je prethodno, kao 11. proleterska brigada mornaričke pješadije, bila podređena Komandi 8. vojnopomorskoga sektora i bila je smještena u kasarni Rade Končar u Sibeniku, odakle je evakuirana između 25. studenoga i 24. prosinca 1991. tijekom odlaska jedinica JNA i JRM sa šibenskoga područja. Nakon evakuacije iz Šibenika jedinica je odlukom Komande 9. korpusa ušla u njegov sastav te je razmještena na području Drvara. Brigović, “Odlazak jedinica JNA,” str. 440-441.

${ }^{24}$ Izbijanjem rata u Bosni i Hercegovini Komanda 9. korpusa JNA osnovala je jedinicu 7. travnja 1992. za zapovijedanje srpskim snagama na području Kupres - Livno - Bugojno. Marijan, Domovinski rat, str. 214.

25 Josipa Caričić, "HR-HMDCDR-7. 9. korpus Jugoslavenske narodne armije (1988-1992)," (sumarni inventar fonda, Hrvatski memorijalno-dokumentacijski centar Domovinskog rata, Zagreb, 2015).
} 
"Treća faza" sređivanja započela je krajem 2017. godine. Tada je identificirano i izdvojeno gradivo 9. korpusa JNA iz dokumentacijskih cjelina preuzetih iz vojarne u Zemuniku Donjem i u četiri navrata od VSOA-e (gradivo je korišteno u sudskim procesima pripadnicima JNA i SVK osumnjičenima da su počinili ratne zločine, pa se nije smjelo izdvajati iz navedenih cjelina prije okončanja istražnih radnji protiv tih osoba), te iz dokumentacije koju su HMDCDR-u predali Jadranko Kaleb (gradivo korpusa nije se smjelo izdvajati iz navedene cjeline dok cjelokupna njezina dokumentacija ne bude detaljno popisana), Pavle Vranjican i Policijska uprava ličko-senjska. Manja količina dokumentacije 9. korpusa JNA naknadno je identificirana i u tehničkim jedinicama za koje je u popisima preuzetim od HDA pisalo da se u njima nalazi gradivo nastalo na okupiranom području Banovine i Korduna. Naknadnim pregledom dokumentacije koju je HMDCDR 2008. preuzeo od SVA MORH-a utvrđeno je da ona sadržava znatnu količinu gradiva 1. motorizirane brigade iz sastava korpusa, koja se u izvorima navodi pod različitim imenima. ${ }^{26}$ Cjelokupno dodatno prikupljeno gradivo korpusa razvrstano je prema organizacijskom ustroju i uloženo u postojeći fond.

Uvrštavanjem novoga gradiva prvotni obim fonda od trideset kutija povećao se na pedeset i osam kutija, odnosno za dvostruko. Fond se prvotno sastojao od petnaest serija s pripadajućim podserijama, a sada se sastoji od šesnaest serija s pripadajućim podserijama. U prvotnoj strukturi postojala je serija Informativna služba 9. korpusa JNA, koja je u novoj strukturi pridodana seriji Komanda 9. korpusa JNA. Za razliku od prvotne, u revidiranoj strukturi fonda postoje dvije nove serije - 1. bataljon 592. motorizirane brigade i Operativna grupa - 11, kao i velik broj novih podserija u već postojećim serijama. Uvrštavanjem novoga gradiva povećao se obim svih serija fonda. Struktura fonda (serije $s$ pripadajućim podserijama) sada je sljedeća:

1. Komanda korpusa (kutije 1-23)

1.1. Istureno komandno mjesto

1.2. Komanda garnizona Knin

1.3. Odsjek za obavještajne poslove

1.4. Organ bezbjednosti

1.5. Grupa za borbeno komandiranje

2. Prištapske jedinice Komande korpusa (kutije 24-33) ${ }^{27}$

2.1. Deveta izviđačka četa

2.2. Deveti inženjerski bataljon

2.3. Deveti automobilski bataljon

26 Usp. bilješku 18.

${ }^{27}$ U prvotnoj strukturi fonda ova serija sastojala se od šest podserija, što je uvećano uvrštavanjem nove podserije: 9. oklopni bataljon. 
2.4. Deveta četa atomsko-biološko-hemijske obrane

2.5. Deveti oklopni bataljon

2.6. Sedamdeseti bataljon veze

2.7. Deveti bataljon vojne policije

3. Dvjesto dvadeset i prva motorizirana brigada (kutije 34-35) ${ }^{28}$

3.1. Istureno komandno mjesto

3.2. Četa vojne policije

3.3. Deseti oklopni bataljon

3.4. Drugi motorizirani bataljon

3.5. Treći motorizirani bataljon

4. Sto i osamdeseta motorizirana brigada (kutije 36-45) ${ }^{29}$

4.1. Istureno komandno mjesto

4.2. Komanda garnizona Benkovac

4.3. Organ bezbjednosti

4.4. Četa vojne policije

4.5. Prvi motorizirani bataljon

4.6. Drugi motorizirani bataljon

4.7. Treći motorizirani bataljon

4.8. Četvrti motorizirani bataljon

4.9. Oklopni bataljon T-34

4.10. Haubički divizion $105 \mathrm{~mm}$

4.11. Mješoviti protuoklopni artiljerijski divizion

4.12. Laki artiljerijski divizion PVO

5. Tristo šesnaesta motorizirana brigada (kutija 45)

6. Prva motorizirana brigada (kutije 46-53) ${ }^{30}$

6.1. Istureno komandno mjesto

6.2. Izviđačka četa

6.3. Četa vojne policije

6.3.1. Služba dežurstva

${ }^{28}$ U prvotnoj strukturi fonda ova serija sastojala se od četiri podserije, što je uvećano uvrštavanjem nove podserije: 3 . motorizirani bataljon.

29 U prvotnoj strukturi fonda ova serija sastojala se od četiri podserije, što je uvećano uvrštavanjem novih osam podserija: 1 . motorizirani bataljon; 2. motorizirani bataljon; 3. motorizirani bataljon; 4. motorizirani bataljon; Oklopni bataljon T-34; Haubički divizion $105 \mathrm{~mm}$; Mješoviti protuoklopni artiljerijski divizion; Laki artiljerijski divizion PVO.

30 U prvotnoj strukturi fonda ova serija sastojala se od jedne podserije, što je uvećano uvrštavanjem novih osam podserija: Izdvojeno komandno mjesto; Izviđačka četa; 1 . motorizirani bataljon; 2. motorizirani bataljon; 3. motorizirani bataljon; 4. motorizirani bataljon; 5. motorizirani bataljon; Mješoviti protuoklopni artiljerijski divizion. 
6.4. Prvi motorizirani bataljon

6.5. Drugi motorizirani bataljon

6.6. Treći motorizirani bataljon

6.7. Četvrti motorizirani bataljon

6.8. Peti motorizirani bataljon

6.9. Mješoviti protuoklopni artiljerijski divizion

7. Jedanaesta proleterska motorizirana brigada/Jedanaesta motorizirana brigada (kutija 54)

8. Prvi bataljon Petsto devedeset i druge motorizirane brigade (kutija 54)

9. Deveti mješoviti artiljerijski puk (kutija 54)

10. Petsto pedeset i sedmi mješoviti protuoklopni artiljerijski puk (kutija 55$)^{31}$

10.1. Inženjerijska četa

10.2. Drugi mješoviti protuoklopni artiljerijski divizion

11. Dvjesto sedamdeset i prvi laki artiljerijski raketni puk PVO (kutija 56$)^{32}$

11.1. Organ bezbjednosti

11.2. Prva laka artiljerijska baterija PVO $40 \mathrm{~mm} \mathrm{L/70}$

11.3. Druga laka artiljerijska baterija PVO $40 \mathrm{~mm} \mathrm{L/70}$

11.4. Instrumentalna baterija

12. Petsto devedeset i četvrti inženjerski puk (kutija 57)

13. Četiristo i peta pozadinska baza (kutija 57) ${ }^{33}$

13.1. Organ bezbjednosti

13.2. Drugo tehničko skladište

13.3. Četvrto tehničko skladište Golubić

13.4. Peto tehničko skladište

13.5. Jedanaesto intendantsko skladište

14. Taktička grupa -1 (kutija 57)

15. Operativna grupa - 11 (kutija 57)

16. Nerazvrstani spisi $^{34}$ (kutija 58). ${ }^{35}$

31 U prvotnoj strukturi fonda ova serija nije imala ni jednu podseriju.

32 U protnoj strukturi fonda ova serija nije imala ni jednu podseriju.

33 U prvotnoj strukturi fonda ova serija nije imala ni jednu podseriju.

34 Riječ je o dokumentima - tri bilješke, pregradni kartoni, personalna dokumentacija, tj. dnevnici, evidencije i popisi, te dokumentacija sustava veze - iz čijega je sadržaja vidljivo da pripadaju gradivu 9. korpusa JNA, ali se ne može identificirati kojoj njegovoj organizacijskoj jedinici.

35 Ivan Brigović i Josipa Caričić, "HR-HMDCDR-7. 9. korpus Jugoslavenske narodne armije (19721992)," (sumarni inventar fonda, Hrvatski memorijalno-dokumentacijski centar Domovinskog rata, Zagreb, 2018). 
Brigović I., Caričić J. Prikupljanje, obrada i korištenje arhivskoga gradiva 9. (kninskog) korpusa Arh. vjesn. 62 (2019), str. 107-126

Nakon opisane revizije, u lipnju 2018. izrađen je novi sumarni inventar. ${ }^{36}$ Riječ je o nadopuni i doradi inventara izrađenoga u travnju 2015. godine. Inventar je izrađen prema ISAD $(\mathrm{G})$-u: općoj međunarodnoj normi za opis arhivskoga gradiva i dostupan je svim korisnicima. Time je završila "treća" i (zasad) posljednja faza sređivanja. Fond je predviđen za trajno čuvanje.

Tijekom arhivističkoga rada na identifikaciji i sređivanju gradiva 9. korpusa JNA naišlo se na brojne poteškoće. Najveći je problem bio što fond izvorno nije činio jednu organsku cjelinu, nego je nastao izuzimanjem gradiva korpusa iz više različitih nesređenih dokumentacijskih cjelina. Stalni priliv novoga gradiva, bilo da je naknadno pronađeno u spremištu, bilo da je naknadno preuzeto, rezultirao je stalnim preslagivanjem gradiva i dopunjavanjem inventara. Nedostatak organizacijskih shema pojedinih jedinica iz sastava korpusa otežao je identifikaciju svih njihovih ustrojbenih cjelina i, samim time, sređivanje gradiva i njegovo uvrštavanje u fond na odgovarajuće mjesto. Vrlo zahtjevna bila je identifikacija i sređivanje gradiva 1 . motorizirane brigade, za koju je, tek pregledavanjem cjelokupnoga gradiva JNA i pobunjenih Srba nastaloga na okupiranom području Like od 1991. do 1992., utvrđeno da je od rujna 1991. do lipnja 1992. promijenila ime više puta te da je gradivo 1. partizanske brigade TO, 1. partizanske brigade, 1. brigade TO SAO Krajine, 1. brigade TO Sveti Rok i 1. motorizirane brigade TO SAO Krajine ustvari gradivo 1. motorizirane brigade 9. korpusa JNA.

Prilikom sređivanja fonda u serije 11. proleterska motorizirana brigada/11. motorizirana brigada, 271. laki artiljerijski raketni puk PVO, 594. inženjerski puk i 405. pozadinska baza, uvršteno je sve pronađeno gradivo tih jedinica, iako su one do jeseni ili zime 1991. bile podređene komandama Vojnopomorske oblasti ili 8. vojnopomorskoga sektora (nakon toga su podređene Komandi 9. korpusa JNA). Prikupljanjem njihova cjelokupnoga gradiva na jednom mjestu željelo se korisnicima olakšati pretraživanje gradiva tih jedinica, jer arhivski fondovi Vojnopomorska oblast i 8. vojnopomorski sektor JNA nisu bili sređeni.

\section{Informacijska vrijednost i dostupnost gradiva fonda}

Arhivski fond 9. korpusa JNA sadržava gradivo Komande korpusa i jedinica iz njegova sastava te njegovih nadređenih komandi nastalo od 1972. do 1992. godine. Iako je gradivo nastalo u razdoblju od dvadeset godina, najveći dio nastao je tijekom postojanja korpusa od kraja 1988. do sredine svibnja 1992. godine, odnosno tijekom ratnih zbivanja, od sredine 1991. do sredine 1992. godine. Dokumenti prije 1988. uglavnom se odnose na personalne stvari (osobni kartoni, medicinska dokumentacija i dosjei) pripadnika korpusa ili je riječ o upitnicima, predmetima i procjenama tijela sigurnosti Komande korpusa, a uklju-

\footnotetext{
36 Brigović i Caričić, „HR-HMDCDR-7”.
} 
čuju i nešto gradiva Komande garnizona Benkovac, 557. mješovitoga protuoklopnog artiljerijskog puka, 271. lakoga artiljerijskog raketnog puka PVO i 405. pozadinske baze. ${ }^{37}$

Korpus je imao sjedište u Kninu i nadzirao je prostor Ravnih kotara, Bukovice i Dalmatinske zagore. U nadležnosti korpusa bili su garnizoni i jedinice JNA u Benkovcu, Kninu i Sinju, ali i dio njih u Zadru, Šibeniku i Splitu. Izbijanjem rata u proljeće 1992. korpus je premješten na područje Bosne i Hercegovine. Reorganizacijom JNA u Bosni i Hercegovini u vojsku bosanskohercegovačkih Srba, sredinom svibnja 1992. od dijela Kninskoga i Bihaćkoga korpusa ustrojen je 2. krajiški korpus sa sjedištem u Drvaru, čija je zona odgovornosti bila zapadna i jugozapadna Bosna.

Sačuvano gradivo dokumentira stanje na području sjeverne Dalmacije i južne Like od početka 1991. do sredine 1992. - od pogoršanja političko-sigurnosne situacije u proljeće 1991., preko izbijanja otvorenoga rata i žestokih borbi u zadnjem kvartalu 1991., do situacije u zoni odgovornosti korpusa nakon sklapanja Sarajevskoga primirja 2. siječnja 1992., kroz prizmu uloge 9. korpusa u navedenim događajima. Gradivo dokumentira ulogu korpusa kao zaštitnika srpske pobune u sjevernoj Dalmaciji i južnoj Lici, njegovu ulogu u ustrojavanju, naoružavanju i obučavanju lokalnih jedinica TO pobunjenih Srba te njihovu suradnju i koordinirano vojno djelovanje tijekom napada na hrvatska sela i gradove. ${ }^{38}$ Otkriva ustrojbeno-organizacijske promjene kroz koje je korpus prošao u drugoj polovici 1991. i prvoj polovici 1992., te odnos Komande korpusa prema nadređenim komandama - Komandi Vojnopomorske oblasti u Splitu, Saveznomu sekretarijatu za narodnu obranu (SSNO-u), odnosno Generalštabu OS SFRJ u Beogradu i Komandi 2. vojne oblasti u Sarajevu. Ilustrira hrvatsko-srpske odnose i situaciju u zoni odgovornosti korpusa (maltretiranje i iseljavanje hrvatskoga stanovništva, paljenje njihovih kuća i pljačku njihove imovine te uništavanje sakralnih objekata). Dokumentira i odlazak komandi, jedinica i ustanova JNA i Jugoslavenske ratne mornarice (JRM) iz garnizona Sinj, Šibenik, Zadar, Split i Divulje krajem 1991. i početkom 1992. u Bosnu i Hercegovinu i Crnu Goru, ali i ulazak dijela ljudstva i artiljerijskih oruđa izvučenih iz garnizona Zadar i Šibenik u sastav jedinica korpusa. Uz prikaz bojnih djelovanja, sadržava informacije o lokalnim pregovorima o prekidu vatre i rješavanju lokalnih incidenata, razmjenama zarobljenika te počinjenju zločina nad nesrpskim stanovništvom, poput masakra hrvatskih civila i zarobljenika u Škabrnji i Nadinu. Dokumentira i planove za ustrojavanje TO i milicije pobunjenih Srba na okupiranom području sjeverne Dalmacije i južne Like (i općenito u RSK), koje je korpus naoružao i

37 Brigović i Caričić, "HR-HMDCDR-7".

38 Od sredine rujna 1991. Komandi 9. korpusa JNA bila je podređena TO pobunjenih Srba na području sjeverne Dalmacije, a u siječnju 1992. u sastavu korpusa bile su i 2. i 3. brigada TO pobunjenih Srba. 
Brigović I., Caričić J. Prikupljanje, obrada i korištenje arhivskoga gradiva 9. (kninskog) korpusa Arh. vjesn. 62 (2019), str. 107-126

opremio te im predao svu imovinu. Sadržani su i podatci o premještanju Komande i jedinica korpusa na područje jugozapadne Bosne i izbijanju rata u Bosni i Hercegovini u proljeće 1992., s naglaskom na borbama na Kupreškoj visoravni i širem području Livna i Šujice. Iz gradiva se jasno vide planovi i ciljevi 9. korpusa JNA u agresiji na Republiku Hrvatsku i njegova uloga u napadnim operacijama prema Zadru, Šibeniku, Drnišu, Sinju i Splitu s ciljem njihova zauzimanja, izbijanja na jadransku obalu i odsijecanja juga Hrvatske, što je lažno pravdano ciljevima kao što su deblokada opkoljenih objekata JNA i JRM u dalmatinskim gradovima, zaštita srpskoga stanovništva od ponavljanja genocida nad njime i obrana prava svih naroda koji žele nastaviti zajednički život u (novoj) Jugoslaviji.

Gradivo je najčešće pisano srpskim (odnosno "srpsko-hrvatskim") jezikom, latinicom ili ćirilicom, te se uglavnom radi o izvornicima. Pisano je na papiru, kartonu i grafofoliji i dobro je očuvano, autentično i vjerodostojno. Jasno i pregledno svjedoči o radu stvaratelja. Neznatna su mehanička oštećenja zbog zahrđalih metalnih spajalica, koja ne utječu na čitljivost spisa. Fond sadržava i manju količinu fotografija i negativa, uglavnom o nesrećama, stradanjima pripadnika korpusa i kaznenim djelima, koje su fotografirali pripadnici 9. bataljona vojne policije tijekom uviđaja. Uvidom u sačuvano gradivo utvrđeno je da ono predstavlja veći dio, ali ne i cjelovitu dokumentaciju nastalu radom stvaratelja. U gotovo svim serijama fonda nedostaje gradivo nastalo 1989. i 1990. godine. U nedostatku obavijesnih pomagala i relevantnih popisa iz ranijega razdoblja ne može se sa sigurnošću reći o kojoj je količini gradiva riječ. Gradivo je prikupljano na netom oslobođenom području Republike Hrvatske u kolovozu 1995., gdje još uvijek u potpunosti nije bila profunkcionirala civilna vlast, pa nije bilo kontrole nad njegovim prometom. Dio je gradiva završio kod privatnih imatelja, od kojih su ga neki već predali HMDCDR-u. No, dio se gradiva korpusa zasigurno još uvijek nalazi kod privatnih imatelja. O kojoj količini je riječ i kod koliko se privatnih imatelja ono nalazi autori, u nedostatku konkretnih podataka, ne mogu reći.

Opisano gradivo ima veliku važnost za razumijevanje rata u Hrvatskoj, posebice na području sjeverne Dalmacije i južne Like u razdoblju od 1991. do 1992., te za razumijevanje izbijanja rata u Bosni i Hercegovini 1992., kao i uloge JNA u raspletu jugoslavenske krize i raspadu nekadašnje zajedničke države. Zbog njegove povijesne važnosti i predstavljanja znanstvenoj, ali i široj javnosti, $s$ ciljem daljnjih istraživanja i znanstvenih raščlambi, HMDCDR je objavio dva zbornika dokumenata gradiva 9. korpusa JNA u sklopu edicije Republika Hrvatska i Domovinski rat 1990.-1995.: Dokumenti, knjiga $19^{39}$ i knjiga 20..$^{40}$ Prvi zbornik dokumenata, na 488 stranica, sadržava 205 dokumenata Komande korpusa i jedinica

\footnotetext{
39 Ivan Brigović i Ivan Radoš, 9. korpus JNA (1991.) (Zagreb: Hrvatski memorijalno-dokumentacijski centar Domovinskog rata, 2016).

40 Ivan Brigović i Ivan Radoš, 9. korpus JNA (1992.) (Zagreb: Hrvatski memorijalno-dokumentacijski centar Domovinskog rata, 2017).
} 
Brigović I., Caričić J. Prikupljanje, obrada i korištenje arhivskoga gradiva 9. (kninskog) korpusa Jugoslavenske narodne armije u Hrvatskom memorijalno-dokumentacijskom centru Domovinskog rata u Zagrebu Arh. vjesn. 62 (2019), str. 107-126

iz njegova sastava te štabova i jedinica TO pobunjenih Srba u sjevernoj Dalmaciji, nastalih od 10. veljače do 30. prosinca 1991. godine. Drugi zbornik dokumenata, na 372 stranice, sadržava 165 dokumenata istih stvaratelja, nastalih od 1. siječnja do 27. svibnja 1992. godine. Uz njih, HMDCDR je objavio dva zbornika dokumenata koji, uz druge dokumente JNA i pobunjenih Srba iz navedenoga razdoblja, sadržavaju više desetaka dokumenata 9. korpusa JNA i njemu podređenih jedinica. Riječ je o zbornicima također objavljenima u ediciji Republika Hrvatska i Domovinski rat 1990.-1995.: Dokumenti, knjiga $1^{41}$ i knjiga $3 .^{42}$ Prvi zbornik sadržava 67 (od ukupno 314) dokumenata Komande korpusa i jedinica iz njegova sastava te štabova i jedinica TO pobunjenih Srba u sjevernoj Dalmaciji, a drugi zbornik sadržava 88 (od ukupno 297) dokumenata istih stvaratelja. Svi zbornici sadržavaju kratke predgovore u kojima se analizira sadržaj dokumenata koji se objavljuju, popise kratica te kazala imena i mjesta.

O povijesnoj važnosti gradiva 9. korpusa JNA svjedoči velik broj znanstvenih i publicističkih radova te monografija koji su nastali (dijelom ili u potpunosti) na temelju toga gradiva kao neizostavnoga povijesnog izvora za proučavanje različitih aspekata (srpska pobuna, hrvatsko-srpski odnosi, ratne operacije, ratni zločini, stradanje sakralne baštine, odlazak komandi, jedinica i ustanova JNA i JRM s područja Dalmacije u Bosnu i Hercegovinu i Crnu Goru) Domovinskoga rata na području sjeverne Dalmacije i južne Like do sredine 1992. godine. Osim toga, gradivo korpusa ima veliku vrijednost i za druge znanosti, kao što su sociologija, ekonomija i demografija.

Gradivo korpusa ima i veliku informacijsku vrijednost za pravosudna tijela Republike Hrvatske i Bosne i Hercegovine, koja su se njime uvelike koristila u istragama protiv osoba (pripadnika korpusa i jedinica TO) osumnjičenih da su počinili kaznena djela i ratne zločine tijekom sukoba na području sjeverne Dalmacije i južne Like te zapadne i jugozapadne Bosne do sredine 1992. godine. U prilog tomu svjedoči podatak da je trideset kutija/registratora dokumenata, koji su se pretežno odnosili na dokumente korpusa, korišteno za izradu Memorijala za tužbu protiv Jugoslavije zbog kršenja odredbi Konvencije o genocidu, koji je Republika Hrvatska podnijela Međunarodnomu sudu pravde u Haagu 2. srpnja 1999. godine. ${ }^{43}$

\footnotetext{
41 Mate Rupić, Oružana pobuna Srba u Hrvatskoj i agresija Oružanih snaga SFRJ i srpskih paravojnih postrojbi na Republiku Hrvatsku (1990.-1991.) (Zagreb: Hrvatski memorijalno-dokumentacijski centar Domovinskog rata, 2007).

${ }_{22}$ Mate Rupić, Oružana pobuna Srba u Hrvatskoj i agresija Oružanih snaga SFRJ i srpskih paravojnih postrojbi na Republiku Hrvatsku (siječanj - lipanj 1992.) (Zagreb: Hrvatski memorijalno-dokumentacijski centar Domovinskog rata, 2008).

43 Republika Hrvatska podnijela je Međunarodnomu sudu pravde tužbu protiv Savezne Republike Jugoslavije (SRJ), odnosno protiv Srbije i Crne Gore, zbog povrede odredbi Konvencije o sprječavanju i kažnjavanju zločina genocida. Nakon njihova razdruživanja i proglašenja neovisnih Crne Gore i Srbije u lipnju 2006., Hrvatska se je na traženje suda izjasnila da postupak nastavlja protiv Srbije, koja je
} 
Gradivo 9. korpusa JNA i obavijesno pomagalo dostupni su svim korisnicima pod jednakim uvjetima, sukladno važećemu Zakonu o arhivskom gradivu i arhivima. ${ }^{44}$ Gradivo fonda javno je arhivsko gradivo, te kao takvo u pravilu dostupno javnosti od nastanka. Ograničenja postoje u korištenju dokumenata koji sadržavaju podatke od važnosti za nacionalnu sigurnost Republike Hrvatske i osobne podatke, odnosno dokumenata nastalih nakon 30. svibnja 1990. koji su izvorno označeni stupnjevima tajnosti. Takvo gradivo može se dati na korištenje prije isteka zakonom propisanih rokova (40 godina za klasificirano gradivo i gradivo od nacionalnoga interesa za RH; 100 godina od rođenja/nakon smrti osobe/70 godina nakon nastanka za gradivo koje sadržava osobne podatke) ako se na temelju propisa o pravu na pristup informacijama i zaštiti tajnosti podataka utvrdi da javni interes koji se ostvaruje dostupnošću podataka preteže nad interesima koji se štite. ${ }^{45}$

Od veljače 2006. do sredine 2019. uvid u arhivsko gradivo 9. korpusa JNA ostvarilo je sedamnaest korisnika, koji su tijekom 41 posjeta ukupno pregledali 184 tehničke jedinice gradiva. Uvid u gradivo najviše su tražila pravosudna tijela - pojedini odvjetnici i Tužiteljstvo $\mathrm{BiH}$ - Agencija za genocid, djelatnici SOA-e i MUP-a Republike Hrvatske u službene svrhe, zbog prikupljanja dokaza za istražne postupke i podizanja optužnica protiv osoba osumnjičenih da su počinili kaznena djela i ratne zločine tijekom Domovinskoga rata. Uz njih, uvid u gradivo tražili su i ostvarili i pojedini povjesničari, kao i druge osobe, u znanstvene svrhe. Detaljniji podatci o učestalosti i svrsi korištenja, navedeni su u Tablici 1.

\footnotetext{
nastavila državnopravni kontinuitet SRJ, države koju je Republika Hrvatska izvorno tužila. Kao odgovor na hrvatsku tužbu, Srbija je u siječnju 2011. podnijela Međunarodnomu sudu pravde protutužbu protiv Hrvatske, optužujući ju da je počinila genocid nad srpskim stanovništvom za vrijeme i nakon VRO Oluja. Međunarodni sud pravde donio je presudu 3. veljače 2015. kojom je odbacio i tužbu Hrvatske protiv Srbije i protutužbu Srbije protiv Hrvatske.

44 Zakon o arhivskom gradivu i arhivima, NN 61/2018.

45 Zakon o arhivskom gradivu i arhivima, NN 61/2018.
} 
Brigović I., Caričić J. Prikupljanje, obrada i korištenje arhivskoga gradiva 9. (kninskog) korpusa Jugoslavenske narodne armije u Hrvatskom memorijalno-dokumentacijskom centru Domovinskog rata u Zagrebu Arh. vjesn. 62 (2019), str. 107-126

Tablica 1. Korisnici koji su ostvarili uvid u gradivo 9. korpusa JNA

\begin{tabular}{|c|c|c|c|c|}
\hline $\begin{array}{l}\text { Redni } \\
\text { broj }\end{array}$ & Korisnik $^{46}$ & $\begin{array}{l}\text { Razdoblje korištenja } \\
\text { gradiva }\end{array}$ & $\begin{array}{l}\text { Broj } \\
\text { tehničkih } \\
\text { jedinica }\end{array}$ & Svrha \\
\hline 1. & I. F. i G. G. & 21. - 31. srpnja 2006. & 8 & $\begin{array}{l}\text { službeni uvid za potrebe } \\
\text { sudskoga postupka }\end{array}$ \\
\hline 2. & I. F. i G. G. & $\begin{array}{l}\text { 26. srpnja - 3. kolovoza } \\
2006 .\end{array}$ & 7 & $\begin{array}{l}\text { službeni uvid za potrebe } \\
\text { sudskoga postupka }\end{array}$ \\
\hline 3. & I. F. i G. G. & 1. - 23. kolovoza 2006. & 8 & $\begin{array}{l}\text { službeni uvid za potrebe } \\
\text { sudskoga postupka }\end{array}$ \\
\hline 4. & I. F. i G. G. & 18. - 23. kolovoza 2006. & 4 & $\begin{array}{l}\text { službeni uvid za potrebe } \\
\text { sudskoga postupka }\end{array}$ \\
\hline 5. & I. F. i G. G. & 21. - 28. kolovoza 2006. & 2 & $\begin{array}{l}\text { službeni uvid za potrebe } \\
\text { sudskoga postupka }\end{array}$ \\
\hline 6. & I. F. i G. G. & 23. - 28. kolovoza 2006. & 8 & $\begin{array}{l}\text { službeni uvid za potrebe } \\
\text { sudskoga postupka }\end{array}$ \\
\hline 7. & V. F. & 28. - 29. kolovoza 2006. & 3 & $\begin{array}{l}\text { službeni uvid za potrebe } \\
\text { sudskoga postupka }\end{array}$ \\
\hline 8. & J. R. & 2. - 10. listopada 2006. & 2 & znanstveno istraživanje \\
\hline 9. & J. R. & 12. - 31. listopada 2006. & 1 & znanstveno istraživanje \\
\hline 10. & J. R. & 5. - 19. siječnja 2006. & 1 & znanstveno istraživanje \\
\hline 11. & L. B. & 10. - 16. svibnja 2007. & 1 & službeni uvid \\
\hline 12. & $\begin{array}{l}\text { M. O. i S. } \\
\text { U. }\end{array}$ & 14. - 15. studeni 2007. & 7 & službeni uvid \\
\hline 13. & S. P. & 16. siječnja 2009. & 2 & znanstveno istraživanje \\
\hline 14. & S. P. & 19. siječnja 2009. & 2 & znanstveno istraživanje \\
\hline 15. & S. P. & 20. - 22. siječnja 2009. & 2 & znanstveno istraživanje \\
\hline 16. & S. P. & 21. - 28. siječnja 2009. & 6 & znanstveno istraživanje \\
\hline 17. & D. P. & 5. - 15. lipnja 2009. & 2 & znanstveno istraživanje \\
\hline 18. & M. H. & 21. - 27. listopada 2009. & 15 & znanstveno istraživanje \\
\hline 19. & J. R. & 3. ožujka 2010. & 2 & znanstveno istraživanje \\
\hline 20. & J. R. & 27. - 28. travnja 2010. & 1 & znanstveno istraživanje \\
\hline 21. & J. W. S. & 6. - 11. svibnja 2010. & 2 & znanstveno istraživanje \\
\hline 22. & SOA & 3. veljače 2011. & 1 & službeni uvid \\
\hline 23. & M. M. & 26. -29. rujna 2011. & 2 & službeni uvid \\
\hline
\end{tabular}

${ }^{46}$ Zbog zaštite osobnih podataka korisnika, umjesto njihovih punih imena i prezimena, navedeni su samo njihovi inicijali. 


\begin{tabular}{|c|c|c|c|c|}
\hline $\begin{array}{l}\text { Redni } \\
\text { broj }\end{array}$ & Korisnik $^{46}$ & $\begin{array}{l}\text { Razdoblje korištenja } \\
\text { gradiva }\end{array}$ & $\begin{array}{l}\text { Broj } \\
\text { tehničkih } \\
\text { jedinica }\end{array}$ & Svrha \\
\hline 24. & D. G. & $\begin{array}{l}\text { 24. travnja - 7. svibnja } \\
2014 .\end{array}$ & 3 & znanstveno istraživanje \\
\hline 25. & $\begin{array}{l}\text { Tužiteljstvo } \\
\text { BiH } \\
\text { - Agencija } \\
\text { za genocid }\end{array}$ & 22. srpnja 2014. & 1 & $\begin{array}{l}\text { službeni uvid za potrebe } \\
\text { sudskoga postupka }\end{array}$ \\
\hline 26. & $\begin{array}{l}\text { Policijska } \\
\text { uprava ličko } \\
\text { - senjska }\end{array}$ & 12. - 13. ožujka 2015. & 5 & službeni uvid \\
\hline 27. & D. G. & $\begin{array}{l}\text { 25. ožujka - 1. travnja } \\
2015 .\end{array}$ & 5 & znanstveno istraživanje \\
\hline 28. & D. G. & 19. - 20. svibnja 2015. & 1 & znanstveno istraživanje \\
\hline 29. & D. G. & $\begin{array}{l}\text { 27. travnja - 4. svibnja } \\
2016 .\end{array}$ & 6 & znanstveno istraživanje \\
\hline 30. & D. G. & 4. - 16. svibnja 2016. & 10 & znanstveno istraživanje \\
\hline 31. & D. G. & 16. - 25. svibnja 2016. & 10 & znanstveno istraživanje \\
\hline 32. & D. G. & 25. - 30. svibnja 2016. & 7 & znanstveno istraživanje \\
\hline 33. & D. G. & $\begin{array}{l}\text { 30. svibnja - 2. lipnja } \\
2016 .\end{array}$ & 7 & znanstveno istraživanje \\
\hline 34. & Z. M. & $\begin{array}{l}\text { 31. svibnja - 14. srpnja } \\
\text { 2016. }\end{array}$ & 10 & znanstveno istraživanje \\
\hline 35. & D. G. & 2. - 7. lipnja 2016. & 3 & znanstveno istraživanje \\
\hline 36. & D. G. & 14. - 21. lipnja 2016. & 2 & znanstveno istraživanje \\
\hline 37. & D. G. & 21. - 30. lipnja 2016. & 3 & znanstveno istraživanje \\
\hline 38. & D. G. & $\begin{array}{l}\text { 30. lipnja - 4. srpnja } \\
\text { 2016. }\end{array}$ & 3 & znanstveno istraživanje \\
\hline 39. & M. Ž. & $\begin{array}{l}\text { 9. siječnja - 10. travnja } \\
2017 .\end{array}$ & 1 & službeni uvid \\
\hline 40. & B. D. & 24. - 25. travnja 2017. & 5 & znanstveno istraživanje \\
\hline 41. & B. D. & 25. - 26. travnja 2017. & 4 & znanstveno istraživanje \\
\hline 42. & B. D. & 11. - 12. travnja 2019. & 2 & znanstveno istraživanje \\
\hline 43. & B. D. & 12. travnja 2019. & 7 & znanstveno istraživanje \\
\hline
\end{tabular}


Brigović I., Caričić J. Prikupljanje, obrada i korištenje arhivskoga gradiva 9. (kninskog) korpusa Jugoslavenske narodne armije u Hrvatskom memorijalno-dokumentacijskom centru Domovinskog rata u Zagrebu Arh. vjesn. 62 (2019), str. 107-126

\section{Zaključak}

Sređivanjem fonda 9. korpusa JNA njegovo gradivo postalo je dostupnije javnosti i znanstvenicima, što je vrlo važno za daljnje istraživanje i razumijevanje rata u Hrvatskoj, posebice na području sjeverne Dalmacije i južne Like od 1991. do 1992., za razumijevanje izbijanja rata u Bosni i Hercegovini 1992., kao i uloge i važnosti JNA u tim događajima. Iz opisanoga je vidljivo da je dokumentacija fonda i prije bila dostupna korisnicima, ali je njezina nesređenost otežavala korištenje i ciljano traženje potrebnih informacija. Gradivo 9. korpusa JNA svojim obimom i, što je puno važnije, svojom informacijskom vrijednošću predstavlja najvažnije gradivo JNA koje se čuva u HMDCDR-u. No, uvidom u cjelinu sačuvanoga gradiva, lako se uočava da dio gradiva, možda i bitan, nedostaje - prvenstveno gradivo korpusa nastalo 1989. i 1990. godine. Gdje je ta dokumentacija - nalazi li se kod privatnih imatelja u Republici Hrvatskoj ili je, zajedno s jedinicama korpusa, "napustila" Hrvatsku u prvoj polovici 1992. - ne može se sa sigurnošću reći. $S$ obzirom na to da su neki privatni imatelji dosad predali poveću količinu gradiva HMDCDR-u, za pretpostaviti je da se dio gradiva 9. korpusa JNA još uvijek nalazi kod privatnih imatelja u Republici Hrvatskoj, što je za opravdanu zabrinutost arhivista, jer nije poznato o kojoj je količini gradiva riječ i kod koga se sve i u kakvim uvjetima čuva.

\section{POPIS IZVORA}

\section{Arhivsko gradivo}

\section{Hrvatski memorijalno-dokumentacijski centar Domovinskog rata}

Pismohrana.

\section{Službena glasila i tisak}

Narodne novine (Zagreb), 2018.

\section{Literatura}

Brigović, Ivan, Ivan Radoš, ur. 9. korpus JNA (1992.). Zagreb: Hrvatski memorijalno-dokumentacijski centar Domovinskog rata, 2017. [Edicija Republika Hrvatska i Domovinski rat 1990.-1995.: Dokumenti, knjiga 20.]

Brigović, Ivan, Ivan Radoš, ur., 9. korpus JNA (1991.). Zagreb: Hrvatski memorijalno-dokumentacijski centar Domovinskog rata, 2016. [Edicija Republika Hrvatska i Domovinski rat 1990.-1995.: Dokumenti, knjiga 19.]

Brigović, Ivan, Josipa Caričić. "HR-HMDCDR-7. 9. korpus Jugoslavenske narodne armije (1972-1992)." Sumarni inventar, Hrvatski memorijalnodokumentacijski centar Domovinskog rata, Zagreb, 2018. 
Brigović I., Caričić J. Prikupljanje, obrada i korištenje arhivskoga gradiva 9. (kninskog) korpusa Jugoslavenske narodne armije u Hrvatskom memorijalno-dokumentacijskom centru Domovinskog rata u Zagrebu Arh. vjesn. 62 (2019), str. 107-126

Brigović, Ivan. "Odlazak Jugoslavenske narodne armije s područja Zadra, Šibenika i Splita krajem 1991. i početkom 1992. godine.” Casopis za suvremenu povijest 43, br. 2 (2011): str. 415-452.

Caričić, Josipa. "HR-HMDCDR-7. 9. korpus Jugoslavenske narodne armije (1988-1992)." Sumarni inventar, Hrvatski memorijalno-dokumentacijski centar Domovinskog rata, Zagreb, 2015.

Marijan, Davor. Domovinski rat. Zagreb: Despot infinitus, 2016.

Marijan, Davor. Slom Titove armije: JNA i raspad Jugoslavije 1987.-1992. Zagreb: Golden marketing, 2008.

Nazor, Ante, Ivan Brigović, ur. Zapovjedni vrh JNA: siječanj 1990. - svibanj 1992. Zagreb: Hrvatski memorijalno-dokumentacijski centar Domovinskog rata, 2010.

Rupić, Mate, ur. Oružana pobuna Srba u Hrvatskoj i agresija Oružanih snaga SFRJ i srpskih paravojnih postrojbi na Republiku Hrvatsku (1990.-1991.). Zagreb: Hrvatski memorijalno-dokumentacijski centar Domovinskog rata, 2007. [Edicija Republika Hrvatska i Domovinski rat 1990.-1995.: Dokumenti, knjiga 1.]

Rupić, Mate, ur. Oružana pobuna Srba u Hrvatskoj i agresija Oružanih snaga SFRJ i srpskih paravojnih postrojbi na Republiku Hrvatsku (siječanj - lipanj 1992.). Zagreb: Hrvatski memorijalno-dokumentacijski centar Domovinskog rata, 2008. [Edicija Republika Hrvatska i Domovinski rat 1990.-1995.: Dokumenti, knjiga 3.]

Summary

COLLECTING, PROCESSING AND USAGE OF ARCHIVAL MATERIALS PERTAINING TO THE ${ }^{\text {TH }}$ (KNIN'S) CORPS OF THE YUGOSLAV PEOPLE'S ARMY STORED IN THE CROATIAN MEMORIAL-DOCUMENTATION CENTER OF HOMELAND WAR IN ZAGREB

The Croatian Memorial Documentation Center of Homeland War in Zagreb stores archival fonds of the $9^{\text {th }}$ (Knin's) Corps of the Yugoslav People's Army, the total of fifty eight boxes (5,8 linear meters) of archives, confiscated by the Croatian forces after the Storm operation in August 1995 in the liberated territory of the Republic of Croatia. Originally the fonds was not an organic whole, but was created by the exclusion of the corps' archives from various and 
unarranged documentation wholes which from December 2005 to March 2018 were handed over to the Center as deposit by the Croatian State Archives, Ministry of Defence of the Republic of Croatia, State Archives in Zadar, Military Security and Intelligence Agency, Lika-Senj Police Administration and several private holders. To a significant extent, that slowed down and made its arrangement harder, while causing numerous difficulties for the Center's employees during the fonds' archival processing. Because of that, fonds was arranged in three phases during several years and it was finished in June 2018. A finding aid was created for the fonds (summary inventory) kept at the Division for Conventional Records of the Center. The fonds' records, dating from 1972 to 1992, are divided into sixteen series with associated sub-series. They are written in Serbian (or so called Serbo-Croatian), in Latin or Cyrillic script. The fonds mostly contains original documents, written on paper, cardboard or transparency. It also contains smaller amount of photographs and negatives. The records are authentic, wellkept and credible, representing the large part but not the entire documentation created by the activity of its creator. The fonds has significant informational value and is an extremely important historical source for research of the Homeland War, especially in the area of north Dalmatia and southern Lika during 19911992, research of the outbreak of war in Bosnia and Herzegovina in spring 1992, as well as for understanding the role of the Yugoslav People's Army in the way the Yugoslav crisis was resolved. Due to its historical importance and in order to bring it closer and present it to the both professional and general public, the Center published four volumes comprising of 525 documents of the Corps' Command and units within it, as well as headquarters and units of the territorial defence of the rebelled Serbs in northern Dalmatia, created from mid-February 1991 to the end of May 1992. The judiciary bodies of Croatia and Bosnia and Herzegovina also used it to a large extent in their investigations of criminal offences and war crimes committed during the conflict in northern Dalmatia and southern Lika, as well as western and south-western Bosnia until mid-1992. Fonds' records were also greatly used to create The Memorial for suing Yugoslavia due to violation of Genocide Convention's provisions, submitted by the Republic of Croatia to the International Court of Justice in Hague on 2 June 1999. Fonds' records are public archives available to all users on equal terms.

Keywords: archives; archival fonds and collections, archival processing; records accessibility; informational value; specialized archives; Homeland War; 9 $9^{\text {th }}$ Corps of the Yugoslav People's Army; Knin's Corps of the Yugoslav People's Army 